\title{
Super Annigeri 1 and improved JG 74: two Fusarium wilt-resistant introgression lines developed using marker-assisted backcrossing approach in chickpea (Cicer arietinum $\mathbf{L}$.
}

\author{
D. M. Mannur • Anita Babbar • Mahendar Thudi - Murali Mohan Sabbavarapu • \\ Manish Roorkiwal - Sharanabasappa B. Yeri • Vijay Prakash Bansal • \\ S. K. Jayalakshmi • Shailendra Singh Yadav • Abhishek Rathore • Siva K. Chamarthi • \\ Bingi P. Mallikarjuna • Pooran M. Gaur • Rajeev K. Varshney (D)
}

Received: 28 June 2018 / Accepted: 27 November 2018 / Published online: 28 December 2018

(C) The Author(s) 2018

\begin{abstract}
Annigeri 1 and JG 74 are elite high yielding desi cultivars of chickpea with medium maturity duration and extensively cultivated in Karnataka and Madhya Pradesh, respectively. Both cultivars, in recent years, have become susceptible to race 4 of Fusarium wilt (FW). To improve Annigeri 1 and JG 74, we introgressed a genomic region conferring resistance against FW race 4 (foc4) through marker-assisted backcrossing using WR 315 as the donor parent. For foreground selection, TA59, TA96, TR19 and TA27 markers were used at Agricultural Research Station, Kalaburagi, while GA16 and TA96 markers were used at Jawaharlal Nehru Krishi Vishwa Vidyalaya, Jabalpur.
\end{abstract}

D. M. Mannur, Anita Babbar and Mahendar Thudi contributed equally to this work.

Key message: Super Annigeri 1 and improved JG 74 with enhanced resistance to race 4 (foc4) of Fusarium wilt and yield developed using marker-assisted backcrossing approach

Electronic supplementary material The online version of this article (https://doi.org/10.1007/s11032-018-0908-9) contains supplementary material, which is available to authorized users.

D. M. Mannur · S. B. Yeri · S. K. Jayalakshmi Agricultural Research Station, University of Agricultural Sciences (UAS)-Raichur, Kalaburagi, Karnataka 585 101, India

A. Babbar · V. P. Bansal · S. Singh Yadav Jawaharlal Nehru Krishi Vishwa Vidyalaya (JNKVV), Jabalpur, Madhya Pradesh 482 004, India
Background selection using simple sequence repreats (SSRs) for the cross Annigeri $1 \times \mathrm{WR} 315$ in $\mathrm{BC}_{1} \mathrm{~F}_{1}$ and $\mathrm{BC}_{2} \mathrm{~F}_{1}$ lines resulted in $76-87 \%$ and $90-95 \%$ recurrent parent genome recovery, respectively. On the other hand, $90-97 \%$ genome was recovered in $\mathrm{BC}_{3} \mathrm{~F}_{1}$ lines in the case of cross JG $74 \times$ WR 315 . Multilocation evaluation of $10 \mathrm{BC}_{2} \mathrm{~F}_{5}$ lines derived from Annigeri 1 provided one superior line referred to as Super Annigeri 1 with $8 \%$ increase in yield and enhanced disease resistance over Annigeri 1. JG 74315-14, the superior line in JG 74 background, had a yield advantage of $53.5 \%$ and $25.6 \%$ over the location trial means in Pantnagar and Durgapura locations, respectively, under Initial Varietal

M. Thudi • M. M. Sabbavarapu • M. Roorkiwal • A. Rathore - S. K. Chamarthi · B. P. Mallikarjuna • P. M. Gaur • R. K. Varshney $(\square)$ International Crops Research Institute for the Semi-Arid Tropics (ICRISAT), Patancheru, Telangana 502 324, India e-mail: r.k.varshney@cgiar.org 
Trial of All India Coordinated Research Project on Chickpea. These lines with enhanced resistance and high yield performance are demonstration of successful deployment of molecular breeding to develop superior lines for FW resistance in chickpea.

Keywords Chickpea · Fusarium wilt · Foreground selection · Background selection · Marker-assisted backcrossing

\section{Introduction}

Chickpea (Cicer arietinum L.) is the second most important food legume, cultivated on residual soil moisture by the resource poor farmers in the South Asia, Indian subcontinent and Sub-Saharan Africa. Besides being proteinrich source for human diet, it also improves soil health and structure by adding nitrogen through symbiotic association with Rhizobium. In addition, valuable malic acid is added to soil through massive amount of fallen leaves which increases nutrient availability. In India, it is grown in a wide range of agro-climatic niches. Based on crop duration, these regions are classified as short (Southern/ peninsular India), medium (Central India) and long (Northern India) duration environments. The major chickpea growing countries include India (67.4\%), Australia (6.21\%), Pakistan (5.73\%), Turkey (3.86\%), Myanmar $(3.74 \%)$ and Iran (2.25\%). Approximately $9.38 \mathrm{~m}$ tons of chickpea was produced during 2016-2017 (http://agricoop.gov.in/sites/default/files/2ND_ADV_ EST_APY_201718_E.pdf).

In India, the chickpea area dramatically declined from 4.7 to $0.7 \mathrm{~m}$ ha in northern states like Punjab, Haryana and Uttar Pradesh between 1965 and 2010 and increased from 2.1 to $6.1 \mathrm{~m}$ ha in central and southern states like Madhya Pradesh, Maharashtra, Andhra Pradesh and Karnataka between 1967 and 2012 (Gowda et al. 2013). This major shift in the cultivated area of chickpea is due to (i) green revolution that intensified irrigated wheat cultivation and (ii) availability of short duration chickpea varieties. Despite of increase in area and production, the productivity has been less than one ton per ha mainly due to adverse effects of biotic and abiotic stresses. The emergence of Fusarium wilt $(\mathrm{FW})$ as a devastating root disease of chickpea in central and southern India has been leading to $100 \%$ yield losses under favourable conditions (Halila and Strange 1996; Sharma et al. 2004; Jendoubi et al.
2017). Fusarium oxysporum f. sp. ciceris is a soilborne pathogenic fungus, which causes FW and differs in pathogenic variability. Based on variation in virulence among isolates of $f o c$ races, eight distinct physiological races were reported namely races $0,1 \mathrm{~A}, 1 \mathrm{~B} / \mathrm{C}, 2,3,4,5$ and 6 (Jendoubi et al. 2017). Among eight races known, the genetics of resistance to six races has been studied extensively (Singh et al. 1987; Kumar 1998; Tullu et al. 1999; Tekeoglu et al. 2000; Rubio et al. 2003; Sharma et al. 2004, 2005). The race 4 is highly prevalent in Karnataka and Madhya Pradesh states. Earlier studies reported that resistance to races $0,1 \mathrm{~A}, 2$ and 4 is either digenic or trigenic, whereas resistance to races 3 and 5 is monogenic (Tullu et al. 1999; Tekeoglu et al. 2000).

Recent advances in genomics research enabled development and application of molecular markers for crop improvement (Thudi et al. 2014; Varshney et al. 2018). In the case of chickpea, ample genomic resources in the form of molecular markers (Nayak et al. 2010; Thudi et al. 2011; Hiremath et al. 2012), genetic maps (Nayak et al. 2010; Thudi et al. 2011; Varshney et al. 2014a), physical map (Varshney et al. 2014b), the draft genome sequence of kabuli chickpea genotype CDC Frontier (Varshney et al. 2013a) and resequencing of several germplasm lines (Thudi et al. 2016a, b) have now become available for chickpea improvement. The genes/QTLs for resistance to six races (0,1A, 2, 3, 4 and 5 ) of FW pathogen have been mapped on to the chickpea genetic map (Sharma et al. 2005; Sabbavarapu et al. 2013; Li et al. 2015). Some superior lines with enhanced tolerance or resistance to abiotic and biotic stresses as well as economically important traits have been developed in legumes (Lucas et al. 2015; Varshney 2016; Parhe et al. 2017; Varshney et al. 2018) using markerassisted backcrossing (MABC). In the case of chickpea, a genomic region (known as "QTL-hotspot") harbouring several QTLs for drought component traits was identified (Varshney et al. 2014a) and successfully introgressed initially into an elite cultivar JG 11 (Varshney et al. 2013b). Preliminary yield trials indicated $12-24 \%$ increase in yield under drought conditions. In addition, the introgression of this genomic region into different genetic backgrounds like KAK 2 and Chefe was also found to enhance the drought tolerance. Further, this genomic region is being intogressed into elite cultivars in Kenya, Ethiopia and India (Thudi et al. 2017). The results encouraged us to harness these resources and enhance FW resistance in elite chickpea cultivars of Karnataka and Madhya Pradesh. 
In a recent base line survey, high yielding, drought tolerance and FW resistance were most preferred characters by farmers and farm women in Karnataka and Madhya Pradesh with highest Garrett Scores (http://www.icrisat.org/what-we-do/impi/projects/t12publications/research-reports/rr-cpkrn.pdf; Ghosh et al. 2014) with an intense emphasis on chickpea cultivars with increased FW resistance. Hence, there is a need to develop high yielding chickpea cultivars with FW resistance. In the present study, we report development of Super Annigeri 1 and improved JG 74 with enhanced yield and resistance to FW using MABC approach.

\section{Materials and methods}

Plant material

Annigeri 1 and JG 74 suceptible to FW race 4 (foc4) were used as recipient parents and WR 315; a chickpea landrace resistant to FW race 4 (foc4) was used as donor parent. Annigeri 1 was developed and released for cultivation, from a landrace Annigeri, in 1978 by University of Agricultural Sciences (UAS), Bangalore. Annigeri 1 is semi-spreading cultivar with medium seed size (16-20 g /100 seeds), matures in 95-100 days and has an average yield of 9-12 Q/ha (Bantilan et al. 2014). JG 74 is an early maturing variety (110-115 days duration) released in 1991 by JNKVV, Jabalpur is most suitable for rainfed conditions of Madhya Pradesh and it has an average yield of 11-13 Q/ha (http://farmer.gov. in/imagedefault/pestanddiseasescrops/pulses.pdf).

DNA extraction and marker genotyping

Young leaf tissues were collected from 20-day-old seedlings and genomic DNA was extracted by following high-throughput mini-DNA extraction protocol as described by Cuc et al. (2008). The DNA was checked for its quantity and quality on $0.8 \%$ agarose gel.

Depending on marker polymorphism between donor and recipient parents, 2-4 simple sequence repeat (SSR) markers (TA59, TA96, TR19, TA27) linked to FW resistance QTLs on CaLG02 and an adjacent marker GA16 were used for foreground selection (Sharma and Muehlbauer 2005; Millan et al. 2006) (Table S1). For background selection, SSR markers equally distributed on chickpea genome were used (Table S2). PCR of SSR markers used for foreground selection and background selection, visualisation of amplified products, separation by capillary electrophoresis was performed as described in the earlier studies (Nayak et al. 2010; Thudi et al. 2011).

Recurrent parent genome recovery (RPGR) is calculated as per Sundaram et al. (2008). In brief, recurrent parent genome recovery

$G=[(X+0.5 \mathrm{Y}) \times 100] N$

where

$N$ total number of parental polymorphic markers screened.

$X$ number of markers showing homozygosity for recurrent parent allele.

$Y$ number of markers showing heterozygosity for parental alleles.

Graphical genotypes were drawn using GGT v.2.0 (van Berloo 2008).

Crossing and selection of genotypes

$M A B C$ at ARS-Kalaburagi

At ARS-Kalaburagi, Annigeri $1 \times$ WR 315 crosses were made using Annigeri 1 as recipient and WR 315 as donor in the crop season of 2009-2010. $F_{1}$ seeds were harvested and sown in the next crop season of 2010 2011. In this season, the confirmed hybrids $\left(F_{1} s\right)$, after verifying with the help of molecular markers, were used as pollen parent to make first backcross with Annigeri 1 . In the $\mathrm{BC}_{1} \mathrm{~F}_{1}$ and $\mathrm{BC}_{2} \mathrm{~F}_{1}$ generations in subsequent crop seasons (2011-2012 and 2012-2013), individual plants that were heterozygous at the foc 4 locus based on foreground selection and having higher recurrent parent genome recovery (RPGR) based on background selection were identified and used for subsequent crossing. In parallel, the desirable plants in $\mathrm{BC}_{2} \mathrm{~F}_{1}$ were selfed to obtain $\mathrm{BC}_{2} \mathrm{~F}_{2}$ in the crop season of 2012-2013.

\section{$M A B C$ at JNKVV, Jabalpur}

At JNKVV, Jabalpur, JG $74 \times$ WR 315 crosses were made using JG 74 as recipient and WR 315 as donor in the crop season of 2009-2010. $F_{1}$ seeds were harvested and sown in the next crop season of 2010-2011. In this season, the confirmed hybrids $\left(F_{1} s\right)$, after 
verifying with the help of molecular markers, were used as pollen parent to make first backcross with JG 74. In the $\mathrm{BC}_{1} \mathrm{~F}_{1}$ (crop season, 2010-2011) and $\mathrm{BC}_{2} \mathrm{~F}_{1}$ (offseason, 2011), individual plants that were heterozygous at the foc 4 locus based on foreground selection were identified and used for subsequent crossing. Recurrent parent genome recovery was estimated in $\mathrm{BC}_{3} \mathrm{~F}_{1}$ generation.

Phenotyping of MABC lines for FW resistance

\section{Agricultural Research Station-Kalaburagi}

The MABC lines $\left(\mathrm{BC}_{2} \mathrm{~F}_{2}\right.$ progenies $)$ along with the parental lines and susceptible check (JG 62) were phenotyped for resistance to race 4 of $\mathrm{FW}$ in a wilt sick plot at ARS-Kalaburagi, Karnataka, India, during crop season of 2013-2014. The wilt sick plot had sufficient inoculum load as indicated by $100 \%$ mortality of the susceptible check JG 62 in the wilt sick plots. Visual observations on appearence of wilt symptoms were recorded at 60 days after sowing and the progenies were classified as resistant (0-20\%), moderately resistant $(21-50 \%)$ and susceptible ( $>50 \%$ ) (Sharma et al. 2005). The superior lines identified in $\mathrm{BC}_{2} \mathrm{~F}_{3}$ progenies were evaluated under replicated trials for disease resistance and yield during 2015-2016. The superior lines were identified based on high fusarium wilt resistance and were further evaluated under multi-location testing (MLT) for yield at three locations (Kalaburagi, Bidar and Dharwad) during the crop season 2016-2017.

\section{JNKVV, Jabalpur}

A total $40 \mathrm{BC}_{3} \mathrm{~F}_{4}$ lines were evaluated at Seed Breeding Farm for agronomic traits and also screened in wilt sick plot at JNKVV, Jabalpur during crop season of 20142015. The lines possessing similar agronomic traits like recurrent (JG 74) and resistant to FW were selected. One superior line JG 74315-14 along with local check, recurrent parent and 10 other entries was evaluated in four locations (Jabalpur, Rewa, Ganjbasoda and Sagar) for yield performance and disease reaction under state varietal trials using RBD design during crop season 20162017. Disease resistance was scored on 1-10 scale, as described earlier by Varshney et al. (2014c).
Statsistical analysis

Pooled and location wise analysis of variance was carried out using PROC MIXED (SAS v9.4, SAS Institute Inc. 2017), considering environment, genotype and replication as fixed. In order to pool the data across the environments, individual environment variances were modelled to error distribution using residual maximum likelihood (REML) procedure. Combined and environment wise least square means (LSMeans) were calculated for genotypes and also performed least significant difference (LSD) for significant genotype effects.

\section{Results}

Markers for foreground and background selection

Based on parental polymorphism, TA82, TA96 and TA27 markers and TA96 and GA16 markers were used at ARS-Kalaburagi and JNKVV, Jabalpur, respectively, for foreground selection (Table S1). A set of 38 and 35 SSR markers distributed uniformly across the chickpea genome were used for background selection in $\mathrm{BC}_{1} \mathrm{~F}_{1}$ and $\mathrm{BC}_{2} \mathrm{~F}_{1}$ generations, respectively, at ARSKalaburagi (Table S2). While a total of 42 polymorphic SSR markers were used for background selection in $\mathrm{BC}_{3} \mathrm{~F}_{1}$ at JNKVV, Jabalpur (Table S2).

Introgression of race-specific resistance into Annigeri 1

A total of $55 \mathrm{~F}_{1} \mathrm{~s}$ were harvested from the cross Annigeri $1 \times$ WR 315 at ARS, Kalaburagi during crop season 2009-2010 (Fig. 1a). These $\mathrm{F}_{1} \mathrm{~s}$ were planted during the crop season of 2010-2011 and of the $55 \mathrm{~F}_{1} \mathrm{~s}, 19$ plants were confirmed as hybrids using polymorphic markers (TA194, TS82 and GA16). Out of 19 confirmed $\mathrm{F}_{1} \mathrm{~s}$, only three $\mathrm{F}_{1} \mathrm{~s}$ were used to make first backcross with Annigeri 1 and generated $241 \mathrm{BC}_{1} \mathrm{~F}_{1}$ seeds. A total of 188 plants obtained from $241 \mathrm{BC}_{1} \mathrm{~F}_{1}$ seeds were used for marker analysis (foreground selection) during the crop season of 2011-2012. As a result, 42 plants were found heterozygous for three markers (TS82, TA96 and TR19). These 42 plants were further subjected to background selection with 38 SSR markers (Table S2) and identified recurrent parent genome recovery (RPGR) in the range of $76-87 \%$ (Table S3). Among these, seven plants with highest RPGR (80.8-87\%) were used for second cycle of backcrossing, and as a result, 470 
$\mathrm{BC}_{2} \mathrm{~F}_{1}$ seeds were harvested. During the crop season 2012-2013, a total of 376 plants obtained from 470 $\mathrm{BC}_{2} \mathrm{~F}_{1}$ seeds were used for marker analysis (foreground selection). As a result, 64 plants were identified as heterozygous for all three foreground markers. On assessing the RPGR of 64 plants using 35 SSR markers (Table S2), 18 plants with high RPGR (90-95\%) were selected (Table S4). A total of $1182 \mathrm{BC}_{2} \mathrm{~F}_{2}$ seeds were harvested from $13 \mathrm{BC}_{2} \mathrm{~F}_{1}$ plants. During crop season 2013-2014, out of the 1182 seeds sown in wilt sick plot, a total of 935 seedlings germinated and on subsequent wilt screening, 816 plants were wilted and a total of 119 plants were identified as resistant to race 4 of FW. A total of $9157 \mathrm{BC}_{2} \mathrm{~F}_{3}$ seeds were harvested from 119 resistant plants (Table S5). The graphical genotype of targeted introgressed donor segment and percentage of background genome recovered in $10 \mathrm{BC}_{2} \mathrm{~F}_{1}$ lines on CaLG02 is summarised in Fig. $1 \mathrm{~b}$.

Introgression of race-specific resistance into JG 74

By using JG 74 as recipient and WR 315 as donor, the cross JG $74 \times$ WR 315 was made during crop season 2009-2010 to generate $F_{1}$ s. Out of $52 F_{1}$ plants generated, $12 \mathrm{~F}_{1} \mathrm{~s}$ were confirmed as hybrids using the polymorphic markers (TA96 and GA16) during off-season (July 2010) (Fig. 2). All $\mathrm{F}_{1} \mathrm{~s}$ were used to make first backcross [(JG $74 \times(\mathrm{JG} 74 \times$ WR 315$)]$; however, only six $\mathrm{BC}_{1} \mathrm{~F}_{1}$ seeds were harvested in September, 2010. All the six $\mathrm{BC}_{1} \mathrm{~F}_{1}$ seeds were sown in the crop season 2010 2011. Foreground selection was done with two SSR markers namely GA16 and TA96. As a result, three heterozygous plants identified were used for second cycle of backcrossing and $21 \mathrm{BC}_{2} \mathrm{~F}_{1}$ seeds were harvested in April, 2011 (Table S6). These $21 \mathrm{BC}_{2} \mathrm{~F}_{1}$ seeds were sown in the off-season (August-November, 2011). After foreground marker analysis, four $\mathrm{BC}_{2} \mathrm{~F}_{1}$ heterozygous plants were used for third backcrossing. As a result, $32 \mathrm{BC}_{3} \mathrm{~F}_{1}$ seeds were obtained in November 2011. Although all $32 \mathrm{BC}_{3} \mathrm{~F}_{1}$ seeds were sown in the crop season December 2011-2012, only $15 \mathrm{BC}_{3} \mathrm{~F}_{1}$ plants were obtained. All 15 plants were found heterozygotes. Background selection based on 42 SSR markers (Table S2) showed 52-97\% RPGR in these plants. A total of $2119 \mathrm{BC}_{3} \mathrm{~F}_{2}$ seeds were harvested from all these $15 \mathrm{BC}_{3} \mathrm{~F}_{1}$ plants in April 2012 (Table S7) and a total of $394 \mathrm{BC}_{3} \mathrm{~F}_{2}$ plants were selected based on JG 74 plant type. From $394 \mathrm{BC}_{3} \mathrm{~F}_{2}$ plants, a total of 66,076 $\mathrm{BC}_{3} \mathrm{~F}_{3}$ seeds were obtained. Approximately 10,000
$\mathrm{BC}_{3} \mathrm{~F}_{4}$ seeds were harvested from $44 \mathrm{BC}_{3} \mathrm{~F}_{3}$ lines during crop season 2013-2014.

Phenotypic performance of Annigeri $1 \mathrm{MABC}$ lines

\section{Disease resistance in wilt sick plot}

During 2013-2014 crop season, 9157 seeds from 119 resistant $\mathrm{BC}_{2} \mathrm{~F}_{2}$ plants were grown as plant to row progenies in wilt sick plot along with the parental lines and wilt susceptible check (JG 62) at ARS-Kalaburagi, Karnataka. Wilt screening revealed that among 119 $\mathrm{BC}_{2} \mathrm{~F}_{3}$ progenies, 71 families were found uniformly resistant to FW, whereas remaining 48 families exhibited either susceptible reaction or segregated into susceptible and resistant types. These 71 resistant lines were advanced to test in replicated trial for yield during the crop season 2014-2015 and 2015-2016. On evaluation of 71 resistant lines under replicated trials during 20152016, 10 best lines with high resistance to FW (disease score ranging from 0 to $4.35 \%$ ) and seed yield (ranging from 1366.67 to $1894.79 \mathrm{~kg} / \mathrm{ha}$ ) were identified (Table S8). The 10 superior lines having high FW resistance were named as Super Annigeri 1 (SA-1) lines (SA1-1, SA1-2, SA1 -3, SA1-4, SA1-5, SA1-6, SA17, SA1-8, SA1-9 and SA1-10). These lines were further evaluated for yield in three locations during the crop season 2016-2017.

\section{Multi-location evaluation of superior lines of chickpea}

Multi-location evaluation of 10 superior lines of Super Annigeril (SA-1) were conducted at three locations (Kalaburagi, Bidar and Dharwad) of Karnataka during 2016-2017. The mean yield data from three locations indicated that the line MLT-SA1-1 recorded high yield (1920 kg/ha) followed by MLT-SA1-2 (1835 kg/ha) compared to the check Annigeri $1(1771 \mathrm{~kg} / \mathrm{ha})$ (Table 1). The disease screening of these lines indicated significantly less FW incidence in the case of MLT-SA1$1(7.10 \%)$ and MLT-SA1-2 (7.55\%) compared to recurrent parent Annigeri 1 (41.40\%) and susceptible check JG 62 (100\%) (Fig. 3). Mean yield performance of all MABC lines tested in the genetic background of Annigeri 1 differed significantly ( $p$ value $<0.05$ ) among themselves at all three locations (Table S9). Among 10 lines, yield performance of MLT-SA1-1 was significantly higher compared to WR-315 (donor parent) in pooled analysis and individual locations except in Dharwad. 

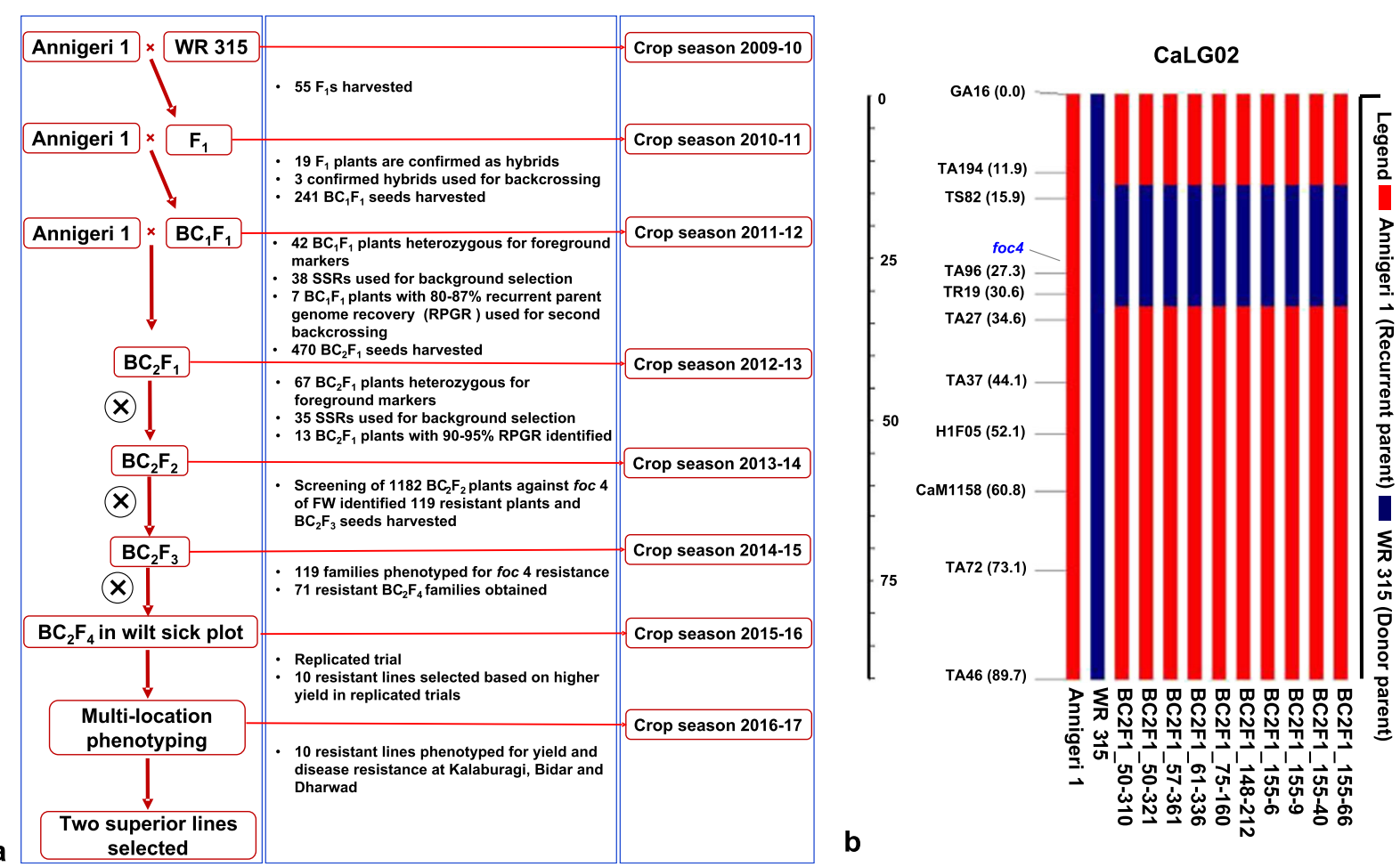

Fig. 1 Marker-assisted backcrossing (MABC) scheme and graphical genotype of superior lines. a MABC scheme adopted to develop superior lines with enhanced resistance to race 4 of Fusarium oxysporum f. sp. ciceris in the genetic background of Annigeri 1 using WR 315 as donor. b Graphical genotype of 10 $\mathrm{BC}_{2} \mathrm{~F}_{1}$ lines for CaLG02. A total of 38 and $35 \mathrm{SSRs}$ equally

Further, MLT-SA1-1 also performed better than Annigeri 1 (recurrent parent) in Bidar and JG 11 (local check) in pooled analysis and at Gulbarga (Table S10). In addition, the mean yield performance of MLT-SA1-2 was significantly high compared to WR 315 (donor parent) in all locations. The yield performance of MLT-SA1-2 was also significantly different from Annigeri 1 (recurrent parent) in Bidar and JG 11 (local check) in pooled analysis and at Gulbarga location (Table S11).

Phenotypic performance of JG 74 MABC lines

All selected $\mathrm{BC}_{3} \mathrm{~F}_{4}$ plants $(\sim 10,000)$ were grown and subjected to phenotyping against race 4 of $\mathrm{FW}$ under field condition at JNKVV, Jabalpur in the crop season 2013-2014. Transgressive segregation for resistance observed in $\mathrm{BC}_{3} \mathrm{~F}_{4}$ (appearance of extreme individuals than the resistant parent) suggests that the parent JG 74 is susceptible to FW and WR 315 possess positive resistant alleles for race 4 . distributed on the genome were used for background selection in $\mathrm{BC}_{1} \mathrm{~F}_{1}$ and $\mathrm{BC}_{2} \mathrm{~F}_{1}$ generations, respectively. Three SSR markers (TA96, TS82 and TR19) and eight SSR markers (GA16, TA194, TA27, TA37, H1F05, CaM1158, TA72 and TA46) were used selecting the donor alleles and recurrent parent genome recovery on $\mathrm{CaLG02}$

The transgressive segregation also suggests the resistance to be quantitative in nature. Two entries (JG 74315-2 and JG 74315-14) based on their performance were nominated for Initial Varietal Trails (IVT) of All India Coordinated Project (AICRP), on chickpea. In IVT trials (crop season 20152016), JG 74315-14 was ranked 4th, as it had yield advantage of $53.5 \%$ and $25.6 \%$ in Pantnagar and Durgapura over the location trial means (Supplementary Information 1). Evaluation for yield performance of JG 74315-14 in state varietal trials in four locations (Jabalpur, Rewa, Ganjbasoda and Sagar) in Madhya Pradesh has shown $125 \%$ and $25 \%$ mean increase in yield over the JG 74 (recurrent parent) and JG 14 (local check), respectively. The mean disease score of JG 74315-14 was 2, which is highly resistant (Table 2). The yield of JG 74315-14 differed significantly over recurrent parent, local check as well as other MABC lines tested in four locations of Madhya Pradesh in state varietal trials during 2016-2017 (Tables S12 and S13). 


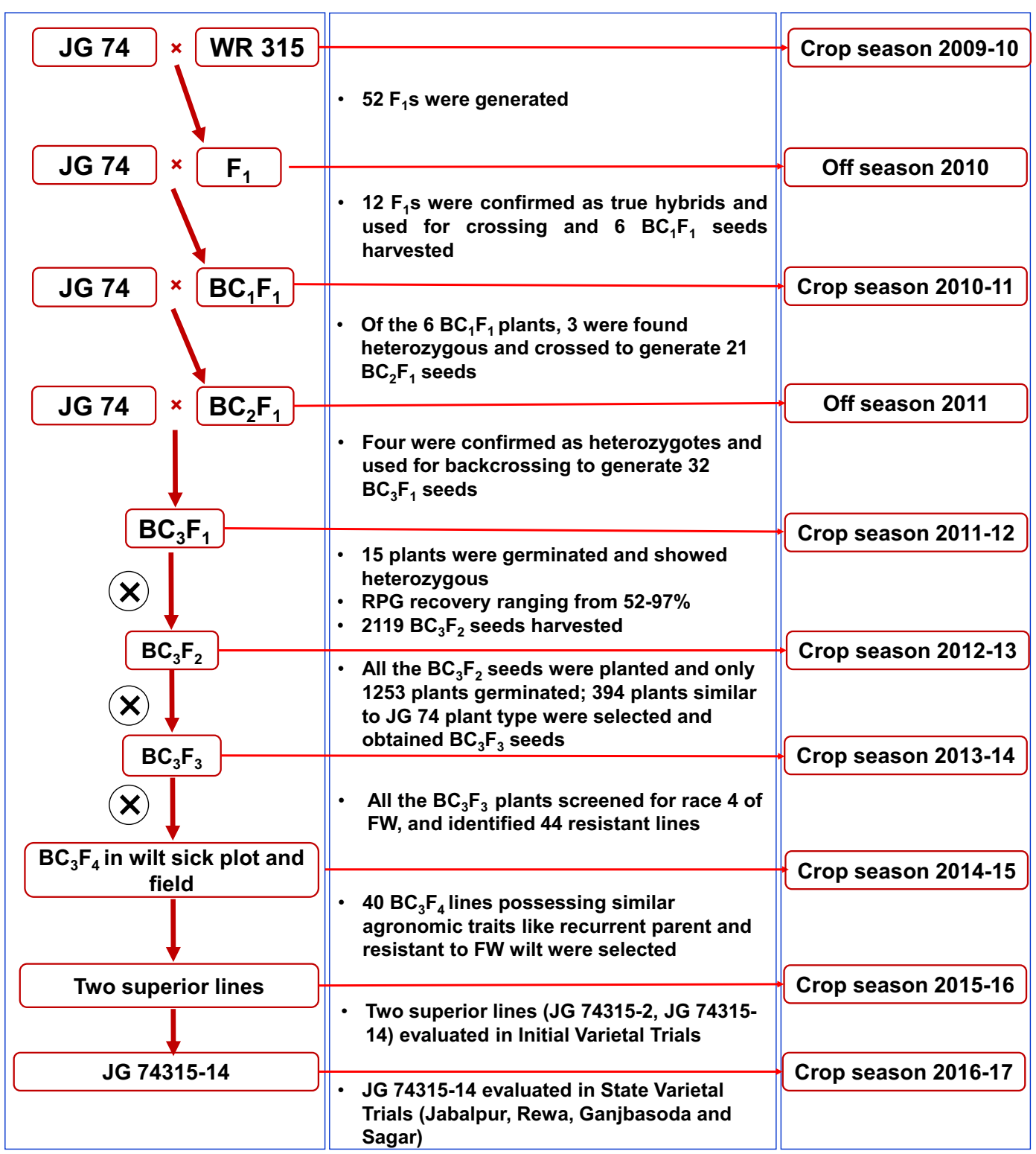

Fig. 2 Marker-assisted backcrossing (MABC) scheme to develop superior lines with enhanced resistance to race 4 of Fusarium oxysporum f. sp. ciceris in the genetic background of JG 74 using

\section{Discussion}

Fusarium wilt is a major disease of chickpea under dry and warm humid conditions leading to significant yield losses. In recent times, this disease has become a major threat due to changing climatic conditions and also a large shift in chickpea growing area from cool long season environments (Northern India) to warm short season environments (Central and Southern India) which exposes the crop to the
WR 315 as donor. Two SSR markers (GA16 and TA96) were used for foreground selection, 42 SSRs were used for background selection in $\mathrm{BC}_{3} \mathrm{~F}_{1}$

disease (Gowda et al. 2013). Since it is a soil-borne disease, chemical control of this pathogen is ineffective. Use of disease-resistant cultivars is the most effective and environmentally safe approach for efficient control of the pathogen (Sharma and Ghosh 2016). In the past, several chickpea improved lines or varieties were developed and released for cultivation in South Asia and Sub-Saharan Africa (see Thudi et al. 2016a). However, the FW-resistant varieties released to date are based on conventional 
Table 1 Yield performance and disease reaction of Super Annigeri (SA) lines of chickpea at three locations of Karnataka during 2016-2017

\begin{tabular}{|c|c|c|c|c|c|c|}
\hline \multirow[t]{2}{*}{ Entries } & \multicolumn{4}{|c|}{ Yield in $\mathrm{kg} / \mathrm{ha}^{*}$} & \multirow[t]{2}{*}{ Increase in yield over Annigeri $1(\%)$} & \multirow[t]{2}{*}{ Disease reaction $(\%)$} \\
\hline & Kalaburagi & Bidar & Dharwad & Mean & & \\
\hline MLT-SA1-1 & 2769 & 1781 & 1210 & 1920 & 8.4 & $7.10(\mathrm{R})$ \\
\hline MLT-SA1-2 & 2718 & 1812 & 975 & 1835 & 3.6 & $7.55(\mathrm{R})$ \\
\hline MLT-SA1-3 & 2606 & 1674 & 1023 & 1768 & - & $9.01(\mathrm{R})$ \\
\hline MLT-SA1-4 & 2341 & 1792 & 1158 & 1764 & - & 12.60 (MR) \\
\hline MLT-SA1-5 & 1715 & 1677 & 1147 & 1513 & - & $22.36(\mathrm{MS})$ \\
\hline MLT-SA1-6 & 2432 & 1410 & 944 & 1595 & - & 11.06 (MR) \\
\hline MLT-SA1-7 & 2411 & 1597 & 1087 & 1698 & - & 12.87 (MR) \\
\hline MLT-SA1-8 & 2761 & 1667 & 1259 & 1896 & 6.95 & 11.05 (MR) \\
\hline MLT-SA1-9 & 2665 & 1524 & 1323 & 1837 & 3.4 & 12.12 (MR) \\
\hline MLT-SA1-10 & 2485 & 1729 & 1208 & 1807 & 1.9 & 16.07 (MR) \\
\hline $\begin{array}{l}\text { Annigeri } 1 \\
\text { (Recurrent parent) }\end{array}$ & 2684 & 1444 & 1186 & 1771 & - & $41.40(\mathrm{~S})$ \\
\hline JG 11 (Local check) & 2115 & 1715 & 1177 & 1669 & - & 18.77 (MR) \\
\hline WR 315 (Donor parent) & 1941 & 1385 & 1348 & 1558 & - & 100.00 (HS) \\
\hline $\mathrm{CV}$ at $5 \%$ & & & & 12.93 & - & $1.34(\mathrm{R})$ \\
\hline $\mathrm{CD}(0.05)$ & & & & 379.28 & - & \\
\hline
\end{tabular}

$R$ resistant, $M R$ moderately resistant, $M S$ moderately susceptible, $S$ susceptible, $H S$ highly susceptible; “_” either no increase in yield or not applicable

* Statistical significance of yield performance of Super Annigeri lines are provided in Tables S7, S8 and S9

screening of the improved or breeding lines in wilt sick plots. Nevertheless, some of these varieties were reported to be susceptible over a period of time that may be due to variability in wilt incidence and genetic differences among the genotypes, genotype $\times$ environment interactions (Neupane et al. 2007; Sharma et al. 2012; Nagar 2013).
Earlier studies revealed that resistance to FW is either monogenic or oligogenic based on the race and the cultivars used in the study. However, resistance to race 4 was reported as recessive and digenic in nature (Tullu et al. 1999). Several studies involving inter- and intraspecific RIL populations revealed the organisation of resistance genes for fusarium

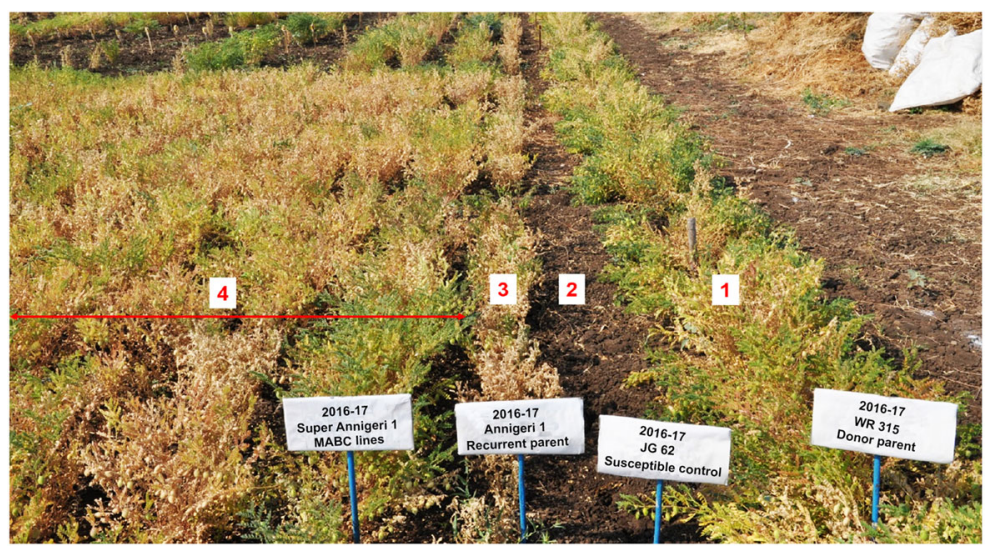

Fig. 3 Evaluation of Super Annigeri lines with Annigeri 1 (recurrent parent), JG 62 (susceptible check) and WR 315 (donor parent) in wilt sick plot at ARS, Kalaburagi during 2016-2017. WR 315, the donor for FW (see row numbered 1); JG 62, the susceptible check, completely wilted and the plants are uprooted (see row numbered 2); wilting symptoms can be seen in case of recipient parent (see row numbered 3); Super Annigeri 1-MABC line with enhanced resistance (see row numbered 3 ) 
Table 2 Yield performance and disease reaction of JG 74315-14 at four locations of Madhya Pradesh during 2016-2017 in state varietal trial

\begin{tabular}{|c|c|c|c|c|c|c|c|}
\hline \multirow[t]{2}{*}{ Entries } & \multicolumn{5}{|c|}{ Yield in $\mathrm{kg} / \mathrm{ha}^{*}$} & \multirow[t]{2}{*}{ Increase in yield over JG $74(\%)$} & \multirow[t]{2}{*}{ Disease reaction (mean) } \\
\hline & Jabalpur & Rewa & Ganjbasoda & Sagar & Mean & & \\
\hline JG $74 \times$ JG 11551 & 2587.2 & 2435.1 & 2099.3 & 2157.6 & 2319.8 & & 2.25 \\
\hline JG $12 \times$ JG $16-3$ & 2587.3 & 2153.4 & 2467.6 & 2386.1 & 2398.6 & & 2.25 \\
\hline JG 2016-45 & 2104.1 & 1885.4 & 2030.9 & 1843.8 & 1966.1 & & 3 \\
\hline JG 2016-43 & 2053.8 & 1995.8 & 1788.7 & 2012.5 & 1962.7 & & 3.5 \\
\hline JG 2016-44 & 2096.2 & 1850.5 & 2107.3 & 1789.6 & 1960.9 & & 3.25 \\
\hline JG 24 & 2560.3 & 2399.8 & 2450.6 & 2245.4 & 2414 & & 2 \\
\hline JG 2016-9605 & 2534.1 & 2222.8 & 2187.1 & 2489.5 & 2358.4 & & 2 \\
\hline ICC $96029 \times$ JG11551 & 2877.9 & 2228.4 & 2455.5 & 2951.4 & 2628.3 & & 2 \\
\hline JG 74315-14 & 2631.9 & 2399.2 & 2523.2 & 2644.4 & 2549.7 & 125 & 2 \\
\hline JG $12 \times$ JG 16 & 2230.5 & 2124.4 & 2155.9 & 2517.4 & 2257.1 & & 2 \\
\hline JG $14 \times$ JG 226 & 2578.6 & 2369.7 & 2249.6 & 2156.3 & 2338.6 & & 2.5 \\
\hline JG 14 (local check) & 2286.7 & 1750.3 & 2006.4 & 2111.1 & 2038.6 & & 3.25 \\
\hline JG 74 (recurrent parent) & 1130.4 & 1258.2 & 1169.2 & 955.2 & 1128.3 & & 8 \\
\hline $\mathrm{CV}(\%)$ & 7.63 & 7.36 & 6.45 & 8.25 & & & \\
\hline $\mathrm{CD}$ at $5 \%$ & 299.22 & 258.30 & 231.42 & 302.37 & & & \\
\hline
\end{tabular}

* Statistical significance of yield performance of JG 74315-14 is provided in Table S10 and Table S11

wilt races 1, 3, 4 and 5 (foc 1 and foc 3 , foc 4 and foc5; Mayer et al. 1997; Ratnaparkhe et al. 1998; Tullu et al. 1998; Winter et al. 2000; Sharma et al. 2004) in two adjacent resistance gene clusters on CaLG02 flanked by STMS markers GA16 and TA96 (foc1-foc4 cluster) and TA96 and TA27 (foc3-foc5 cluster), respectively (Millan et al. 2006). Moreover, several potential resistance and pathogenesis-related genes were localised on the CaLG02 (Huettel et al. 2002; Pfaff and Kahl 2003). Millan et al. (2006) therefore speculated that CaLG02 is a hot spot for pathogen defence. Recently, QTLs for foc4 locus for race 4 were identified by Sharma and Muehlbauer (2005) and Millan et al. (2006). QTLs for resistance to FW were reported earlier mainly on CaLG02 and CaLG04 (Cobos et al. 2009; Gowda et al. 2009). Nevertheless, novel QTLs were also mapped on CaLG05 and CaLG06 (Sabbavarapu et al. 2013; Garg et al. 2018). Previous efforts in identifying different FW-resistant genes (Sharma et al. 2005), race-specific unique and rare alleles (Sharma et al. 2014), tagging of molecular markers linked to resistance (Sharma and Muehlbauer 2005) can accelerate the development of improved cultivars in chickpea through MABC.
Annigeri 1 and JG 74 the most popular varieties in Karnataka and Madhya Pradesh, respectively, have become susceptible to Fusarium wilt due to incidence of the pathogen in farmer fields after 2008-2009. As a result, there has been a significant reduction in breeder seed production and indent for these varieties as per Department of Agriculture and Cooperation, Ministry of Agriculture and Farmers' Welfare, Government of India (Fig. S1). In view of this, the present study was undertaken to introgress the foc 4 locus conferring resistance to race 4 of FW (prevalent in Karnataka and Madhya Pradesh) into Annigeri 1 and JG 74 by employing MABC at ARS-Kalaburagi and JNKVV, Jabalpur. WR 315, a desi landrace from central India resistant to races like $1 \mathrm{~A}$, race 2 , race 3 , race 4 and race 5 with target loci for resistance to foc4 (Sharma and Muehlbauer 2005), was chosen as the donor parent.

The marker TA96 has been reported to be linked with resistant genes against all the four prevalent races of wilt viz.: foc1, foc $2, f \circ c 3$ and foc 4 by the genetic distance of $4.9 \mathrm{cM}, 1.5 \mathrm{cM} 0.5 \mathrm{cM}$ and $3.3 \mathrm{cM}$, respectively (Winter et al. 2000; Sharma and Muehlbauer 2007; Cobos et al. 2009; Gowda et al. 2009; Halila et al. 2009). Recombinants were selected after each backcross generation using tightly linked marker TA96 $(3.3 \mathrm{cM}$ from 
the foc 4 locus) and flanking markers TS82, and TR19 in the case of backcross progenies derived from Annigeri $1 \times$ WR 315 cross. While in the case of backcross progenies derived from JG $74 \times$ WR 315 cross, recombinants were selected using tightly linked marker TA96 and flanking markers GA16 and TS82. All markers (GA16, TS82, TA96 and TR19) having the sequence information (primer sequence) were anchored on to the reference genome (Varshney et al. 2013a) on pseudomolecule $\mathrm{Ca} 2$. Based on the physical position of the markers, 997 genes were identified in the chickpea genome in the region between GA16 and TR19 markers. Interestingly the Ca_14301, that encodes NBARC domain disease resistance protein, closer to TA96 and TR19 linked with foc4 locus was proven to be important candidate gene for resistance to fusarium disease caused by foc 4 in cucumber (https://patents. google.com/patent/WO2015143867A1/en).

MABC approach helped us to introgress resistance to race 4 (foc4) of Fusarium wilt into Annigeri 1 and JG 74 along with rapid RPGR. In the present study, 95\% and 97\% RPGR was achieved in $\mathrm{BC}_{2} \mathrm{~F}_{1}$ and $\mathrm{BC}_{3} \mathrm{~F}_{1}$ generations in the case of MABC lines developed in the genetic backgrounds of Annigeri 1 and JG 74, respectively. Similar genome recovery was reported earlier by Varshney et al. (2014c). The use of MABC enabled to achieve $95 \%$ RPGR in early generations $\left(\mathrm{BC}_{2} \mathrm{~F}_{1}\right.$ derived from Annigeri $1 \times \mathrm{WR} 315$ cross), which could be otherwise achieved only in $\mathrm{BC}_{3} \mathrm{~F}_{1}$ and $\mathrm{BC}_{4} \mathrm{~F}_{1}$ through conventional breeding method. Successful application of MABC approach in chickpea in introgressing drought (Varshney et al. 2013b), FW (Varshney et al. 2014c; Pratap et al. 2017), Ascochyta blight (Varshney et al. 2014c) into elite cultivars has unequivocally proved the advantage of MABC in breeding improved cultivars. In chickpea, superior lines with enhanced resistance to focl (Varshney et al. 2014c) and foc2 (Pratap et al. 2017) were developed in the genetic backgrounds of C 214 and Pusa 256 elite chickpea cultivars, respectively. Hence, MABC can be considered as fasttrack method to breed and develop the resistant varieties for biotic stresses like FW. This has also clearly indicated the advantage of using codominant markers like SSRs for background selection in recovering higher per cent of RPGR in early generations. Higher RPGR was reported using as low as 13 markers in groundnut (Varshney et al. 2014d) to as high as 88 markers in rice (Vu et al. 2012). Recent studies revealed that MABC involving two improved or released varieties can further reduce the time period for improving popular varieties (Iftekharuddaula et al. 2011; Septiningsih et al. 2015).

Field level phenotyping of backcross progenies was carried out to confirm the wilt reaction. During wilt screening, 10 backcross progenies with highest level of RPGR exhibited a high level of resistance ( 0 $4.35 \%)$ compared to the disease incidence in Annigeri $1(70 \%)$ and susceptible check JG 62 (100\%). Evaluation of these 10 superior lines for yield performance across 3 locations of Karnataka provided 2 superior lines, i.e. MLT-SA1-1 (1920 kg/ha) and MLT-SA1-2 $(1835 \mathrm{~kg} / \mathrm{ha})$ with the highest mean yield $8 \%$ and $3.6 \%$ increase over Annigeri 1 (1771 kg/ha), respectively (Table 1). Also, these improved lines showed good level of FW resistance, while the recurrent parent Annigeri 1 was observed as susceptible. The yield performance of MLT-SA1-1 and MLT-SA1-2 differed significantly ( $p$ value $<0.05$ ) over the recurrent and donor parents as well as local check at Bidar and Kalaburagi during 2016-2017. These two superior MABC lines were proposed to evaluate in Advanced Varietal Trials (AVT) under All India Coordinated Research Project (AICRP) on chickpea to assess their performance at national level for possible release as improved cultivars for commercial cultivation. At JNKVV, Jabalpur after generating $\mathrm{F}_{1} \mathrm{~s}$, and three rounds of backcrossing $\left(\mathrm{BC}_{1} \mathrm{~F}_{1}, \mathrm{BC}_{2} \mathrm{~F}_{1}, \mathrm{BC}_{3} \mathrm{~F}_{1}\right)$ and selfing $\left(\mathrm{BC}_{3} \mathrm{~F}_{2}, \mathrm{BC}_{3} \mathrm{~F}_{3}\right.$, $\mathrm{BC}_{3} \mathrm{~F}_{4}$ ) the backcross progenies were phenotyped in wilt-sick plot and selected only the positive plants with high level of resistance from each generation against race 4 (foc4). In state varietal trials, mean disease reaction of JG 74315-14 was 2, which is highly resistant (Fig. S2). In terms of yield performance, JG 74315-14 has $125 \%$ and $25 \%$ mean increase in yield over the JG 74 (recurrent parent) and JG 14 (local check), respectively (Table 2). The yield of JG 74315-14 differed significantly over recurrent parent, local check as well as other MABC lines tested in four locations of Madhya Pradesh in state varietal trials during 2016-2017.

In summary, using MABC approach, we successfully introgressed resistance to $\mathrm{FW}$ race 4 (foc 4 ) into Annigeri 1 and JG 74, the ruling varieties in Karnataka and Madhya Pradesh, respectively, which became susceptible to FW. We also demonstrated $125 \%$ and $25 \%$ mean yield advantage of JG 74315-14 over recurrent parent and local check, respectively, in the state varietal trials conducted during 2016-2017. While Super Annigeri 1 has $8 \%$ mean yield advantage over the Annigeri 1, the improved version of Annigeri 1 based on screening in 
Kalaburagi, Bidar and Dharwad during 2016-2017. These improved lines with enhanced resistance can be released as varieties for cultivation and also can be used as donors for enhancing disease resistance in other elite cultivars.

Authors' contributions Contributed equally: DMM, AB, MT; Conceived and designed the experiments: RKV; Supervised research: RKV, MT; Performed the experiments: SBY, VP, SSY, MMS, SKC, BPM; Analysed the data: MT, MMS, AR, MR, SBY, BPM, SSY; Contributed to materials: PMG, JSK, DMM, AB; Written the Manuscript: RKV, MT, BPM, DMM, AB; All authors read and approved the MS.

Funding information This work received funding from Deparment of Biotechnology (BT/PR11693/AGR/02/641/2008 \& 22 October 2009), Government of India and Government of Karnataka (under KWDP II, Sujala III dated 5 January 2016).

\section{Compliance with ethical standards}

Conflict of interest The authors declare that they have no conflict of interest.

Open Access This article is distributed under the terms of the Creative Commons Attribution 4.0 International License (http:// creativecommons.org/licenses/by/4.0/), which permits unrestricted use, distribution, and reproduction in any medium, provided you give appropriate credit to the original author(s) and the source, provide a link to the Creative Commons license, and indicate if changes were made.

Publisher's Note Springer Nature remains neutral with regard to jurisdictional claims in published maps and institutional affiliations.

\section{References}

Bantilan C, Kumara Charyulu D, Gaur PM, Davala MS, Davis J (2014) Short Duration Chickpea Technology: Enabling Legumes Revolution in Andhra Pradesh, India. Documentation. ICRISAT, Patancheru

Cobos MJ, Winter P, Kharrat M, Cubero JI, Gil J, Millan T, Rubio J (2009) Genetic analysis of agronomic traits in a wide cross of chickpea. Field Crop Res 111:130-136

Cuc LM, Mace E, Crouch J, Quang VD, Long TD, Varshney RK (2008) Isolation and characterization of novel microsatellite markers and their application for diversity assessment in cultivated groundnut (Arachis hypogaea). BMC Plant Biol $8: 55$

Garg T, Mallikarjuna BP, Thudi M, Samineni S, Singh S, Sandhu JS, Kaur L, Singh I, Sirari A, Basandrai AK, Basandrai D, Varshney RK, Gaur PM (2018) Identification of QTLs for resistance to Fusarium wilt and Ascochyta blight in a recombinant inbred population of chickpea (Cicer arietinum L.). Euphytica 214:45

Ghosh R, Pande S, Telangre R, Kathal D, Singh S, Usmani G, Patel A, Rao SK, Mishra S, Pachuri A, Verma S, Sharma RN, Gaur PM, Sharma M (2014) Participatory varietal selection of chickpea in rainfed rice fallow lands of Chhattisgarh and Madhya Pradesh in India for sustainable crop production. Int J Plant Production 8(2) ISSN: 1735-6814

Gowda SJM, Radhika P, Kadoo NY, Mhase LB, Gupta VS (2009) Molecular mapping of wilt resistance genes in chickpea. Mol Breed 24:177-183

Gowda CLL, Samineni S, Gaur PM, Saxena KB (2013) Enhancing the producitivity of pulses in India. In: Shetty PK, Ayyappan S, Swaminathan MS (eds) Climate change and sustainable food security. National Institute of advanced studies. Bangalore and Indian Council of Agricultural Research, New Delhi ISBN: 978-81-87663-76-8

Halila MH, Strange RN (1996) Identification of the causal agent of wilt of chickpea in Tunisia as Fusariumo xysporum f. sp. cicero race 0 . Phytopathol Mediterr 35:67-74

Halila I, Cobos MJ, Rubio J, Millán T, Kharrat M, Marrakchi M, Gil J (2009) Tagging and mapping a second resistance gene for fusarium wilt race 0 in chickpea. Eur J Plant Pathol 124: $87-92$

Hiremath PJ, Kumar A, Penmetsa RV, Farmer A, Schlueter JA, Chamarthi SK, Whaley AM, Garcia NC, Gaur PM, Upadhyaya HD, KaviKishor PB, Shah TM, Cook D, Varshney RK (2012) Large-scale development of costeffective SNP marker assays for diversity assessment and genetic mapping in chickpea and comparative mapping in legumes. Plant Biotechnol J 10:716-732

Huettel B, Santra D, Muehlbauer F, Kahl G (2002) Resistance gene analogues of chickpea (Cicer arietinum L.): isolation, genetic mapping and association with a Fusarium resistance gene cluster. Theor Appl Genet 105:475-490

Iftekharuddaula K, Newaz M, Salam M, Ahmed H, Mahbub M, Septiningsih E, Collard B, Sanchez D, Pamplona A, Mackill D (2011) Rapid and high-precision marker assisted backcrossing to introgress the SUB1 QTL into BR11, the rainfed lowland rice mega variety of Bangladesh. Euphytica 178:83-97

Jendoubi W, Bouhadida M, Boukteb A, Béji M, Kharrat M (2017) Fusarium wilt affecting chickpea crop. Agriculture 7:23

Kumar S (1998) Inheritance of resistance to fusarium wilt (race 2) in chickpea. Plant Breed 117:139-142

Li H, Rodda M, Gnanasambandam A, Aftab M, Redden R, Hobson K, Rosewarne G, Materne M, Kaur S, Slater AT (2015) Breeding for biotic stress resistance in chickpea: progress and prospects. Euphytica 204:257-288

Lucas MR, Huynh B-L, Roberts PA, Close TJ (2015) Introgression of a rare haplotype from southeastern Africa to breed California blackeyes with larger seeds. Front Plant Sci 6:126

Mayer MS, Tullu A, Simon CJ, Kumar J, Kaiser WJ, Kraft JM, Muehlbauer FJ (1997) Development of a DNA marker for fusarium wilt resistance in chickpea. Crop Sci 37:1625-1629

Millan T, Clarke HJ, Siddique KHM, Buhariwalla HK, Gaur PM, Kumar J, Gil J, Kahl J, Winter P (2006) Chickpea molecular breeding: new tools and concepts. Euphytica 147:81-103

Nagar GP (2013) Pathogenic variability, mycelial compatibility and incompatibility groups ofFusariumoxysporum $f$. $s p$. 
ciceriin chickpea (Cicer arietinum L.). MSc Thesis Jawaharlal Nehru Krishi Vishwa Vidyalaya, Jabalpur p 62

Nayak SN, Zhu H, Varghese N, Datta S, Choi HK, Horres R, Jüngling R, Singh J, Kishor PB, Sivaramakrishnan S, Hoisington DA, Kahl G, Winter P, Cook DR, Varshney RK (2010) Integration of novel SSR and gene-based SNP marker loci in the chickpea genetic map and establishment of new anchor points with Medicago truncatula genome. Theor Appl Genet 120:1415-1441

Neupane RK, Sharma M, Jha P, Narayana Rao J, Rao BV, Gaur PM, Pande S (2007) Evaluation of chickpea genotypes for resistance to fusarium wilt in Nepal. An open access journal published by ICRISAT. http://agropedialabs.iitk.ac. in/openaccess/sites/default/files/cp4.pdf. Accessed 2 June 2018

Parhe SD, Chimote VP, Deshmukh MP, Chandra K, Akash M (2017) Marker-assisted pyramiding of four QTL/genes for Asian rust (Phakopsora pachyrhizi) resistance in soybean. J. Crop Improv 31:689-711

Pfaff T and Kahl G (2003) Mapping of gene-specific markers on the genetic map of chickpea (Cicer arietinum L.). Mol Genet Genomics 269:243-51

Pratap A, Chaturvedi SK, Tomar R, Rajan N, Malviya N, Thudi M, Saabale PR, Prajapati U, Varshney RK, Singh NP (2017) Marker-assisted introgression of resistance to fusarium wilt race 2 in Pusa 256, an elite cultivar of desi chickpea. Mol Gen Genomics 293:1237-1245

Ratnaparkhe MB, Santra DK, Tullu A, Muehlbauer FJ (1998) Inheritance of inter-simple-sequence-repeat polymorphisms and linkage with a fusarium wilt resistance gene in chickpea. Theor Appl Genet 96:348-353

Rubio J, Hajj-Moussa E, Kharrat M, Moreno MT, Millan T, Gil J (2003) Two genes and linked RAPD markers involved in resistance to Fusarium oxysporum f. sp. ciceris race 0 in chickpea. Plant Breed 122:188-191

Sabbavarapu M, Sharma M, Chamarthi SK, Swapna N, Rathore A, Thudi M, Gaur PM, Pande S, Singh S, Kaur L, Varshney RK (2013) Molecular mapping of QTLs for resistance to fusarium wilt (race 1) and Ascochyta blight in chickpea (Cicer arietinum L.). Euphytica 193:121-133

SAS Institute Inc (2017) SAS OnlineDoc® 9.3. SAS Institute Inc, Cary

Septiningsih EM, Hidayatun N, Sanchez DL, Nugraha Y, Carandang J, Pamplona AM, Collard BC, Ismail AM, Mackill DJ (2015) Accelerating the development of new submergence tolerant rice varieties: the case of CiherangSub1 and PSB Rc18-Sub1. Euphytica 202:259-262

Sharma M, Ghosh R (2016) An update on genetic resistance of chickpea to Ascochyta blight. Agronomy 6:18

Sharma KD, Muehlbauer FJ (2005) Genetic mapping of Fusarium oxysporum f. sp. ciceris race-specific resistance genes in chickpea (Cicer arietinum L.). In: International food legume research conference-IV. Indian Agricultural Research Institute, New Delhi, pp 18-22

Sharma KD, Muehlbauer FJ (2007) Fusarium wilt of chickpea: physiological specialization, genetics of resistance and resistance gene tagging. Euphytica 157:1-14

Sharma KD, Winter P, Kahl G, Muehlbauer FJ (2004) Molecular mapping of Fusarium oxysporum f. sp. ciceris race 3 resistance gene in chickpea. Theor Appl Genet 108:1243-1248
Sharma KD, Chen W, Muehlbauer FJ (2005) Genetics of chickpea resistance to five races of fusarium wilt and a concise set of race differentials for Fusarium oxysporum $\mathrm{f}$. sp ciceris. Plant Dis 89:385-390

Sharma M, Kiran Babu T, Gaur PM, Ghosh R, Rameshwar T, Chaudhary RG, Upadhyay JP, Gupta O, Saxena DR, Kaur L, Dubey SC, Anandani VP, Harer PN, Rathore A, Pande S (2012) Identification and multi-environment validation of resistance to Fusarium oxysporum f. sp ciceris in chickpea. Field Crop Res 135:82-88

Sharma M, Nagavardhini A, Thudi M, Ghosh R, Pande S, Varshney RK (2014) Development of DArT markers and assessment of diversity in Fusarium oxysporum f. sp. ciceris, wilt pathogen of chickpea (Cicer arietinum L.). BMC Genomics 15:454

Singh H, Kumar J, Haware MP (1987) Genetics of resistance to fusarium wilt in chickpeas. In: Day PR, Jellis GJ et al (eds) Genetics and plant pathogenesis. Blackwell Scientific Publications, Oxford, pp 339-342

Sundaram RM, Vishnupriya MR, Biradar SK, Laha GS, Reddy GA, Rani NS, Sarma NP, Sonti RV (2008) Marker assisted introgression of bacterial blight resistance in Samba Mahsuri, an elite indica rice variety. Euphytica 160:411-422

Tekeoglu M, Tullu A, Kaiser WJ, Muehlbauer FJ (2000) Inheritance and linkage of two genes that confer resistance to fusarium wilt in chickpea. Crop Sci 40:1247-1251

Thudi M, Bohra A, Nayak SN, Varghese N, Shah TM, Varma RP, Nepolean T, Gudipati S, Gaur PM, Kulwal PL, Upadhyaya HD, Kavikishor PB, Winter P, Kahl G, Town CD, Kilian A, Cook DR, Varshney RK (2011) Novel SSR markers from BAC-End sequences, DArT arrays and a comprehensive genetic map with 1,291 marker loci for chickpea (Cicer arietinum L.). PLoS One 6:e27275

Thudi M, Gaur PM, Krishnamurthy L, Mir RR, Kudapa H, Fikre A, Kimurto P, TripathiS SKR, Mulwa R, Bharadwaj C, Datta S, Chaturvedi SK, Varshney RK (2014) Genomics-assisted breeding for drought tolerance: a dream comes true in chickpea! Funct Plant Biol 41:1178-1190

Thudi M, Chitikineni LX, He W, Roorkiwal M, Yang W, Jian J, Doddamani D, Gaur PM, Rathore A, Samineni S, Saxena RK, Xu D, Singh NP, Chaturvedi SK, Zhang G, Wang J, Datta SK, Xu X, Varshney RK (2016a) Recent breeding programs enhanced genetic diversity in both desi and kabuli varieties of chickpea (Cicer arietinum L.). Sci Rep 6:38636

Thudi M, Khan AW, Kumar V, Gaur PM, Katta AVSK, Garg V, Roorkiwal M, Samineni S, Varshney RK (2016b) Whole genome re-sequencing reveals genome wide variations among parental lines of mapping populations in chickpea (Cicer arietinum). BMC Plant Biol 16:10

Thudi M, Roorkiwal M, Kudapa H, Chaturvedi SK, Singh NP, Varshney RK (2017) An overview of chickpea research: from discovery to delivery. Pulse India 2:22-25

Tullu A, Muehlbauer FJ, Simon CJ, Mayer MS, Kumar J, Kaiser WJ, Kraft JM (1998) Inheritance and linkage of a gene for resistance to race 4 of fusarium wilt and RAPD markers in chickpea. Euphytica 102:227-232

Tullu A, Kaiser WJ, Kraft JM, Muehlbauer FJ (1999) A second gene for resistance to race 4 of fusarium wilt in chickpea and linkage with a RAPD marker. Euphytica 109:43-50

van Berloo R (2008) GGT 2.0: versatile software for visualization and analysis of genetic data. J Hered 99:232-236 
Varshney RK (2016) Exciting journey of 10 years from genomes to fields and markets: some success stories of genomicsassisted breeding in chickpea, pigeonpea and groundnut. Plant Sci 242:98-107

Varshney RK, Song C, Saxena RK, Azam S, Yu S, Sharpe AG, Cannon S, Baek J, Rosen BD, Taran B, Millans T, Zhang X, Ramsay LD, Iwata A, Wang Y, Nelson W, Farmer AD, Gaur PM, Sodarlund C, Penmetsa RV, Xu C, Bharti AK, He W, Winter P, Zhao S, Hane JK, Garcia NC, Condie JA, Upadhyaya HD, Luo MC, Thudi M, CLL G, Singh NP, Lichtenzveig J, Gali KK, Rubio J, Nadarajan N, Dolezel J, Bansal KC, Xu X, Edwards D, Zhang G, Khal G, Gil J, Singh KB, Datta SK, Jackson SA, Wang J, Cook DR (2013a) Draft genome sequence of chickpea (Cicer arietinum) provides a resource for trait improvement. Nat Biotechnol 31:240-246

Varshney RK, Gaur PM, Chamarthi SK, Krishnamurthy L, Tripathi S, Kashiwagi J, Samineni S, Singh VK, Thudi M, Jaganathan D (2013b) Fast-track introgression of " $Q T L$ hotspot" for root traits and other drought tolerance traits in JG 11, an elite and leading variety of chickpea. Plant Genome 6:1-9

Varshney RK, Thudi M, Nayak SN, Gaur PM, Kashiwagi J, Krishnamurthy L, Jaganathan D, Koppolu J, Bohra A, Tripathi S, Rathore A, Jukanti AK, Jayalakshmi V, Vemula A, Singh S, Yasin M, Sheshshayee MS, Viswanatha KP (2014a) Genetic dissection of drought tolerance in chickpea (Cicer arietinum L.). Theor Appl Genet 127:445-462

Varshney RK, Mir RR, Bhatia S, Thudi M, Hu Y, Azam S, Zhang Y, Jaganathan D, You FM, Gao J, Riera-Lizarazu O, Luo MC (2014b) Integrated physical, genetic and genome map of chickpea (Cicer arietinum L.). Funct Integr Genomics 14: 59-73

Varshney RK, Mohan SM, Gaur PM, Chamarthi SK, Singh VK, Srinivasan S, Swapna N, Sharma M, Singh S, Kaur L, Pande S (2014c) Marker-assisted backcrossing to introgress resistance to Fusarium wilt race 1 and Ascochyta blight in C 214, an elite cultivar of chickpea. Plant Genome 7:1-11

Varshney RK, Pandey MK, Pasupuleti J, Nigam SN, Sudini H, Gowda MVC, Sriswathi M, Radhakrishan T, Manohar SS, Patne N (2014d) Marker-assisted introgression of a QTL region to improve rust resistance in three elite and popular varieties of peanut (Arachis hypogaea L.). Theor Appl Genet 127:1771-1781

Varshney RK, Thudi M, Pandey MK, Tardieu F, Ojiewo C, Vadez V, Whitbread AM, Siddique KHM, Nguyen HT, Carberry PS, Bergvinson D (2018) Accelerating genetic gains in legumes for the development of prosperous smallholder agriculture: integrating genomics, phenotyping, systems modelling and agronomy. J Exp Bot 69:3293-3312

Vu HTT, Le DD, Ismail AM, Le HH (2012) Marker-assisted backcrossing (MABC) for improved salinity tolerance in rice (Oryza sativa L.) to cope with climate change in Vietnam. Australian J Crop Sci 6:1649-1654

Winter P, Benko-Iseppon AM, Hüttel B, Ratnaparkhe M, Tullu A, Sonnante G, Pfaff T, Tekeoglu M, Santra D, Sant VJ, Rajesh PN, Kahl G, Muehlbauer FJ (2000) A linkage map of the chickpea (Cicer arietinum L.) genome based on recombinant inbred lines from a $C$. arietinum $\times C$. reticulatum cross: localization of resistance genes for fusarium wilt races 4 and 5. Theor Appl Genet 101:1155-1163 